\title{
Study on Rock Mechanics Parameters of Chang 7 Shale in Longdong Area in Ordos Basin
}

\author{
Zhenhua $\mathrm{Li}^{1 *}$, Zhanjun Chen ${ }^{1}$, Suya Zhang ${ }^{2}$, and Xiangyang $\mathrm{Li}^{3}$ \\ ${ }^{1}$ School of Energy Engineering, Longdong University, 745000, Qingyang, China \\ ${ }^{2}$ School of Foreign Languages, Longdong University, 745000, Qingyang, China \\ ${ }^{3}$ Gansu Coalfield Geology Bureau, 745000, Qingyang,China
}

\begin{abstract}
Rock samples from X-1 and X-2 well of Chang 7 shale in Longdong area in Ordos Basin are studied through triaxial compression test and acoustic wave test in order to obtain accurate data about the mechanical characteristics of the stratum and fracturing parameters. The static Young's modulus ranges from $2.213 \mathrm{GPa}$ to $4.195 \mathrm{GPa}$ and the static Poisson's ratio ranges from 0.181 to 0.239 in triaxial compression test. The dynamic Young's modulus ranges from $2.659 \mathrm{GPa}$ to $5.03 \mathrm{GPa}$ and the dynamic Poisson's ratio ranges from 0.20 to 0.29 in acoustic wave test. It can be seen that the dynamic Young's modulus is slightly larger than the static Young's modulus, and the relation between them is $\mathrm{E}_{\mathrm{s}}=0.8492 \mathrm{E}_{\mathrm{d}}-$ 0.1349, while the dynamic and static Poisson's ratios are basically same, that is, $\mu_{\mathrm{s}} \approx \mu_{\mathrm{d}}$.
\end{abstract}

\section{Introduction}

Rock mechanics parameters include static and dynamic parameters. Static parameter is obtained by triaxial compression test of rock samples. It is accurate and reliable, but time-consuming, laborious and costly[1]. Therefore, it is only suitable for a small number of core samples calibration. Dynamic parameter is obtained by measuring the propagation velocity of ultrasonic wave in rocks, which can dynamically and continuously reflect the mechanical characteristics, but in most cases, it needs to be converted into static parameter. The static parameter in laboratory and the dynamic parameter from well logging are combined in order to establish a suitable rock mechanics parameter model which can accurately reflect the stratum mechanical characteristics[2]. In this paper, static and dynamic rock mechanics parameters of Chang 7 shale in Longdong area and the relation between them are studied, which will provide a basis for the researches of mechanical characteristics, brittleness and fracability of rock.

\section{General situation of the study area}

\subsection{Location of the study area}

Ordos Basin is a huge multi-energy mineral basin developed on a stable craton, which contains abundant coal, oil, natural gas and other resources [3,4]. Longdong area is located in the southwestern part of the Ordos Basin, mainly spanning two primary structural units of the Tianhuan Depression and the Yishan Slope (Fig. 1). Chang 7 sedimentary period is the peak of lake basin development of Yanchang period in Ordos basin[5].
Strong tectonic activity and warm and humid climate in the study area resulted in rapid expansion of lake basin and deposited a lot of high-quality source rocks[6]. Rapid expansion of lake basin, continuous and stable deep-water sediments, low salinity and oxygen deficit provide favorable geological conditions for large-scale development of Chang 7shale. The burial depth of Chang 7 shale in the study area ranges from $1200 \mathrm{~m}$ to $2350 \mathrm{~m}$.

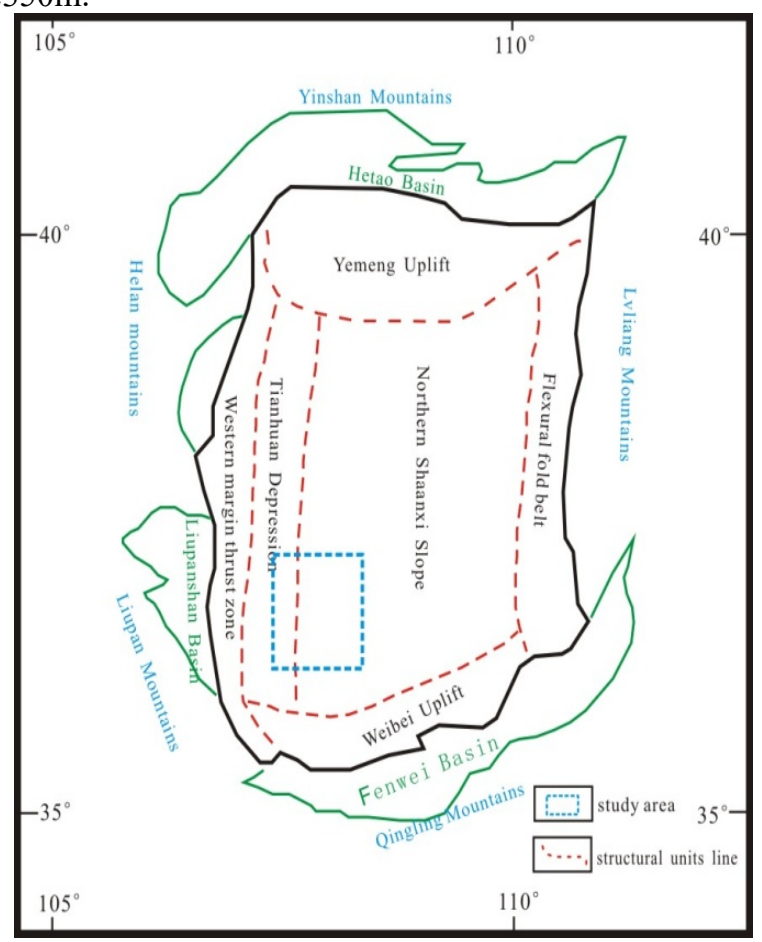

Fig 1. The study area in Ordos Basin 


\subsection{Lithological characteristics of Chang 7shale}

Chang 7 shale in study area is mainly dark gray, grayblack and black in color, and contains a large number of plant fossils (Fig.2) and a small amount of iron nodules, showing the characteristics of deep and semideep lake facies sediments[7]. The main minerals in the shale are quartz, feldspar and clay minerals, in addition to a small amount of carbonate and pyrite.
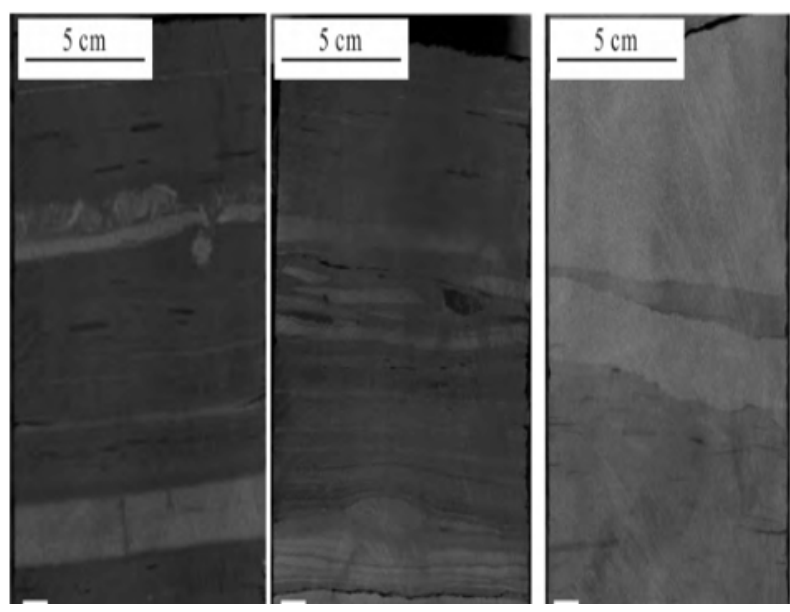

Fig 2. Photos of Chang 7 dark shale in study area

\section{Rock mechanics parameters of Chang 7 shale}

\subsection{Static rock mechanics parameters}

Young's modulus and Poisson's ratio of rocks are the main parameters for describing elastic deformation of rocks and measuring their resistance to deformation. According to the stress-strain relationship of the rock samples under loading, the static mechanical parameter is obtained. Triaxial compression test is carried out in rock samples from X-I and X-2 well of Chang 7 shale in Longdong area in Ordos Basin (the size of rock samples is $38.1 \mathrm{~mm} \times \mathrm{h} 76.2 \mathrm{~mm}$ ). The test results are shown in Table 1.

As for the rock samples from X-1 well of Chang 7 shale, The static Young's modulus ranges from 3.697 $\mathrm{GPa}$ to $4.195 \mathrm{GPa}$, with an average of $3.937 \mathrm{GPa}$, and the static Poisson's ratio ranges from 0.188 to 0.232 , with an average of 0.214 . The static Young's modulus of rock samples from X-2 well ranges from 2.213 to $2.553 \mathrm{GPa}$, with an average of $2.411 \mathrm{GPa}$, and the static Poisson's ratio ranges from 0.181 to 0.239 , with an average of 0.204 .

Table 1.Results of triaxial compression test

\begin{tabular}{|c|c|c|c|c|c|c|c|}
\hline Well & Lithology & $\begin{array}{l}\text { Depth } \\
\text { (m) }\end{array}$ & Sample & $\begin{array}{c}\text { Density } \\
\rho_{d} \\
\left(\mathrm{~g} / \mathrm{cm}^{3}\right)\end{array}$ & $\begin{array}{c}\text { Confining } \\
\text { pressure } \\
\text { (MPa) }\end{array}$ & $\begin{array}{c}\text { Young's } \\
\text { modulus } \\
\text { E (GPa) }\end{array}$ & $\begin{array}{c}\text { Poisson's } \\
\text { ratio } \\
\mu\end{array}$ \\
\hline \multirow{12}{*}{$X-1$} & \multirow{11}{*}{$\begin{array}{c}\text { Fine } \\
\text { sandstone }\end{array}$} & \multirow{11}{*}{$\begin{array}{c}1407- \\
1412\end{array}$} & X1-1 & 2.665 & \multirow[t]{4}{*}{ C्mo } & 3.697 & 0.188 \\
\hline & & & $X 1-2$ & 2.659 & & 3.818 & 0.200 \\
\hline & & & $X 1-3$ & 2.661 & & 3.826 & 0.210 \\
\hline & & & Average & & & 3.780 & 0.199 \\
\hline & & & X1-4 & 2.666 & \multirow{4}{*}{10} & 3.886 & 0.226 \\
\hline & & & X1-5 & 2.667 & & 3.932 & 0.229 \\
\hline & & & X1-6 & 2.651 & & 3.899 & 0.223 \\
\hline & & & Average & & & 3.906 & 0.226 \\
\hline & & & X1-7 & 2.670 & \multirow{4}{*}{20} & 4.167 & 0.232 \\
\hline & & & X1-8 & 2.668 & & 3.999 & 0.201 \\
\hline & & & X1-9 & 2.644 & & 4.195 & 0.223 \\
\hline & \multirow{13}{*}{ Mudstone } & & Average & & & 4.120 & 0.219 \\
\hline \multirow{12}{*}{$X-2$} & & & X2-1 & 2.589 & \multirow{4}{*}{5} & 2.303 & 0.181 \\
\hline & & & $X 2-2$ & 2.607 & & 2.451 & 0.189 \\
\hline & & & X2-3 & 2.606 & & 2.213 & 0.195 \\
\hline & & & Average & & & 2.322 & 0.188 \\
\hline & & & X2-4 & 2.598 & \multirow{4}{*}{15} & 2.385 & 0.182 \\
\hline & & $1758-$ & $X 2-5$ & 2.593 & & 2.384 & 0.239 \\
\hline & & 1759 & X2-6 & 2.577 & & 2.493 & 0.196 \\
\hline & & & Average & & & 2.421 & 0.206 \\
\hline & & & X2-7 & 2.624 & \multirow{4}{*}{25} & 2.519 & 0.188 \\
\hline & & & X2-8 & 2.587 & & 2.457 & 0.213 \\
\hline & & & X2-9 & 2.596 & & 2.553 & 0.237 \\
\hline & & & Average & & & 2.510 & 0.213 \\
\hline
\end{tabular}

between velocity of waves and rock mechanics parameters can be obtained (1), (2).

\subsection{Dynamic rock mechanics parameters}

Under the assumption of homogeneity and isotropy of rocks and based on Newton's law of motion and linear elasticity theory, the equations about the relation

$$
\begin{aligned}
& V_{p}=\sqrt{\frac{E_{d}\left(1-\mu_{d}\right)}{\rho\left(1+\mu_{d}\right)\left(1-2 \mu_{d}\right)}} \\
& V_{s}=\sqrt{\frac{E_{d}}{2 \rho\left(1+\mu_{d}\right)}}
\end{aligned}
$$


From the above equations, we can get the following (3), (4):

$$
\begin{aligned}
& E_{d}=\frac{\rho V_{p}^{2}\left(3 V_{p}^{2}-4 V_{s}^{2}\right)}{V_{p}^{2}-V_{s}^{2}} \\
& \mu_{d}=\frac{V_{p}^{2}-2 V_{s}^{2}}{2\left(V_{p}^{2}-V_{s}^{2}\right)}
\end{aligned}
$$

In the equations, $E_{d}$ is dynamic Young's modulus, $\mathrm{GPa}, \mathrm{u}_{\mathrm{d}}$ is dynamic Poisson's ratio of rock, dimensionless, $\rho$ is volume density, $\mathrm{g} / \mathrm{cm}^{3}, \mathrm{~V}_{\mathrm{p}}$ is $\mathrm{P}$-wave velocity, $\mathrm{m} / \mathrm{s}$, and $\mathrm{V}_{\mathrm{s}}$ is $\mathrm{S}$-wave velocity, $\mathrm{m} / \mathrm{s}$.

It can be seen that the dynamic mechanics parameters of rock can be calculated if the rock density and the propagation velocity of waves are obtained.
Acoustic wave test is carried out on rock samples from X-1 and X-2 well of Chang 7 shale in the study area (the size is $38.1 \mathrm{~mm} \times \mathrm{h} 76.2 \mathrm{~mm}$ ). The velocity of Pwave and S-wave can be obtained by measuring the propagation time of waves along the length direction, and then the dynamic Young's modulus and Poisson's ratio can be calculated (Table2).

Acoustic wave test results show that the dynamic Young's modulus of rock samples from X-1 well of Chang 7 shale in study area is 3.979-5.03 GPa, with an average of $4.457 \mathrm{GPa}$, and the dynamic Poisson's ratio range is $0.20-0.26$, with an average of 0.232 . The dynamic Young's modulus of samples from X-2 well ranges from 2.659 to $3.557 \mathrm{GPa}$, with an average of $2.987 \mathrm{GPa}$, and the dynamic Poisson's ratio ranges from 0.22 to 0.29 , with an average of 0.24 .

\begin{tabular}{|c|c|c|c|c|c|c|c|c|c|}
\hline$\underset{1}{\text { Wel }}$ & Lithology & $\underset{(\mathrm{m})}{\text { Depth }}$ & Sample & $\begin{array}{c}\text { Density } \\
\rho_{d} \\
\left(\mathrm{~g} / \mathrm{cm}^{3}\right)\end{array}$ & $\begin{array}{l}\text { Confining } \\
\text { pressure } \\
(\mathrm{MPa})\end{array}$ & $\begin{array}{l}\text { P-wave } \\
\text { velocity } \\
(\mathrm{m} / \mathrm{s})\end{array}$ & $\begin{array}{l}\text { S-wave } \\
\text { velocity } \\
(\mathrm{m} / \mathrm{s})\end{array}$ & $\begin{array}{l}\text { Young's } \\
\text { modulus } \\
\mathrm{E}(\mathrm{GPa})\end{array}$ & $\begin{array}{c}\text { Poisson's } \\
\text { ratio } \\
\mu\end{array}$ \\
\hline \multirow{11}{*}{$X-1$} & \multirow{11}{*}{$\begin{array}{c}\text { Fine } \\
\text { sanstone }\end{array}$} & \multirow{11}{*}{$\begin{array}{l}1407- \\
1412\end{array}$} & $\mathrm{X} 1-1$ & 2.665 & \multirow{4}{*}{5} & 4511 & 2749 & 4.848 & 0.20 \\
\hline & & & $\mathrm{X} 1-2$ & 2.659 & & 4175 & 2464 & 3.979 & 0.23 \\
\hline & & & $X 1-3$ & 2.661 & & 4374 & 2486 & 4.146 & 0.26 \\
\hline & & & Average & & & 4353 & 2566 & 4.324 & 0.230 \\
\hline & & & $X 1-4$ & 2.666 & \multirow{4}{*}{10} & 4581 & 2804 & 5.030 & 0.20 \\
\hline & & & $\mathrm{X} 1-5$ & 2.667 & & 4356 & 2512 & 4.201 & 0.25 \\
\hline & & & X1-6 & 2.651 & & 4247 & 2533 & 4.162 & 0.22 \\
\hline & & & Average & & & 4394 & 2616 & 4.464 & 0.223 \\
\hline & & & $\mathrm{X} 1-7$ & 2.670 & \multirow{4}{*}{20} & 4585 & 2595 & 4.543 & 0.26 \\
\hline & & & $\mathrm{X} 1-8$ & 2.668 & & 4460 & 2591 & 4.457 & 0.25 \\
\hline & & & X1-9 & 2.644 & & 4486 & 2687 & 4.654 & 0.22 \\
\hline \multirow{13}{*}{$X-2$} & \multirow{13}{*}{ Mudstone } & & Average & & & 4510 & 2624 & 4.551 & 0.243 \\
\hline & & & X2-1 & 2.589 & \multirow{4}{*}{5} & 3498 & 2093 & 2.767 & 0.22 \\
\hline & & & $\mathrm{X} 2-2$ & 2.607 & & 3477 & 2089 & 2.768 & 0.22 \\
\hline & & & $X 2-3$ & 2.606 & & 3408 & 2048 & 2.659 & 0.22 \\
\hline & & & Average & & & 3461 & 2077 & 2.731 & 0.220 \\
\hline & & & $X 2-4$ & 2.598 & \multirow{4}{*}{15} & 3559 & 2105 & 2.832 & 0.23 \\
\hline & & 1758.1 & $X 2-5$ & 2.593 & & 3585 & 2148 & 2.916 & 0.22 \\
\hline & & 1758.9 & $X 2-6$ & 2.577 & & 3672 & 2105 & 2.865 & 0.26 \\
\hline & & & Average & & & 3605 & 2119 & 2.871 & 0.237 \\
\hline & & & $\mathrm{X} 2-7$ & 2.624 & \multirow{4}{*}{25} & 3666 & 2184 & 3.063 & 0.22 \\
\hline & & & $\mathrm{X} 2-8$ & 2.587 & & 4238 & 2310 & 3.557 & 0.29 \\
\hline & & & $\mathrm{X} 2-9$ & 2.596 & & 3862 & 2222 & 3.209 & 0.25 \\
\hline & & & Average & & & 3922 & 2239 & 3.279 & 0.253 \\
\hline
\end{tabular}

Table 2. Results of acoustic wave test 


\section{Relation between dynamic and static rock mechanics parameters}

The fracturing of the strata is a relatively slow static process while the mechanics parameters of rock measured by acoustic wave test are dynamic parameters[8,9]. If the relation between dynamic and static parameter is established, the static mechanics parameter could be obtained.

It can be seen from Table 1 and Table 2 that the static Poisson's ratio and the dynamic Poisson's ratio of Chang 7 shale in Longdong area are basically same, that is, $\mu_{\mathrm{s}} \approx \mu_{\mathrm{d}}$.

Through linear regression of dynamic and static modulus of rock samples from X-1 and X-2 well in Chang 7 shale in the study area, the following equation can be obtained (Fig. 3).

$$
E_{s}=0.8942 E_{d^{-}}-0.1349 \quad R^{2}=0.8673
$$

In the above equation, $\mathrm{E}_{s}$ is the static Young's modulus, $\mathrm{GPa}, \mathrm{E}_{d}$ is the dynamic Young's modulus, GPa, and $\mathrm{R}^{2}$ is the related coefficient.

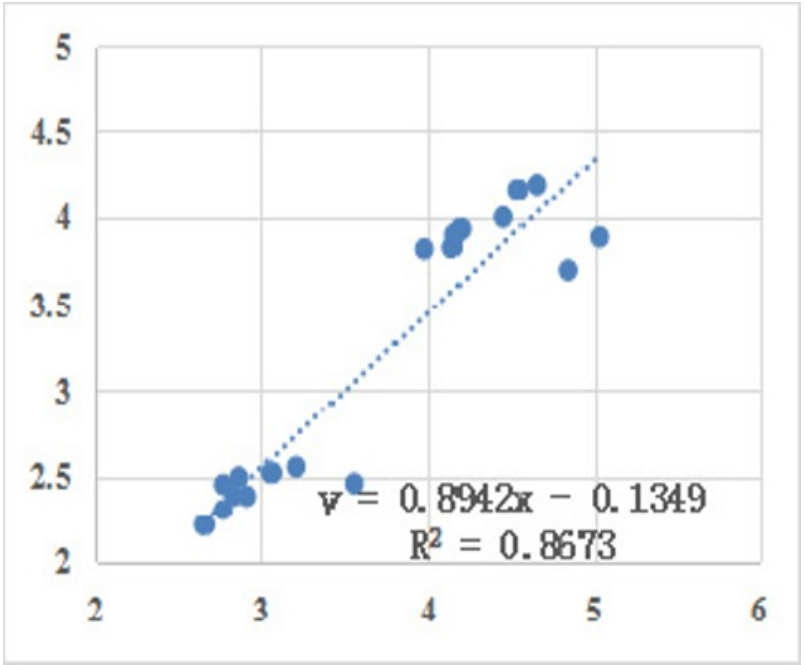

Fig 3. The relation between static and dynamic Young's modulus

\section{Conclusion}

The static Young's modulus of rock samples of Chang 7 shale in Longdong area is $2.213 \sim 4.195 \mathrm{GPa}$, and the static Poisson's ratio range is $0.181 \sim 0.239$ in triaxial compression test. The dynamic Young's modulus obtained from acoustic wave test ranges from 2.659 to 5.03GPa, and the dynamic Poisson's ratio ranges from 0.20 to 0.29 . The dynamic and static Young's modulus of the Chang 7 shale in Longdong area is well correlated, the dynamic parameters are slightly larger than the static parameters, the relation between them is $\mathrm{E}_{\mathrm{s}}=0.8492 \mathrm{E}_{\mathrm{d}}$ 0.1349 , and the dynamic and static Poisson's ratio are basically same, that is, $\mu_{\mathrm{s}} \approx \mu_{\mathrm{d}}$.

\section{Acknowledgement}

This work was financially supported by Higher Education Funds of Gansu Province, project number 2015-148A, by Qingyang Natural Fund Project, project number ZJ201301, and also by Youth Technology Fund of Longdong University, project number XYZK1703.

\section{References}

1. Quan Gao, Junliang Tao, et al. Laboratory study on the mechanical behaviors of an anisotropic shale rock, Journal of Rock Mechanics and Geotechnical Engineering, (2015)

2. Ganchuan Xu,Guanghai Zhong, Bing Xie,et al.Shale Brittle Logging Evaluation Method Based on Petrophysical Experiments, Nature gas industry, (2014)

3. Wenhui Huang,Weihua Ao,Chengmin Weng.The characteristics and genesis of Jurassic coal in Ordos basin.Modern geology, (2010)

4. JunjieYang.Tectonic evolutionandOil-gas reservoirs distribution inOrdos Basin. Beijing:Petroleum Industry Press, (2002)

5. Hua Yang, Xianyang Liu, Sedimentary facies analysis of Chang 7 of Triassic Yanchang Formation in Ordos Basin, J.Journal of sedimentation, (2010)

6. Jian Yu, Yajuan Yang. Sedimentary Characteristics of Late Triassic Yanchang Formation during Lacustrine Transgression in Ordos Basin, J. Petroleum Exploration and Development, (2010)

7. Chuang Er, Jingzhou Zhao, Characteristics of organic-rich shale facies in Chang 7 member of the triassic Yangzhen formation in Huachi area, Ordos Basin, The frontier of geoscience, (2016)

8. Xiaoyan Qin, Zhenliang Wang.Brittle geophysical logging evaluation of continental shale based on rock mechanics characteristics. Progress in Geophysics, (2016)

9. K. K. Chong, W. Griese, O .A. Jaripatke, et al. A Completions guide book to shale-play development: a review of successful approaches toward shale-play stimulation in the last two decades, Beijing, China: SPE International Oil and Gas Conference and Exhibition(2010) 